\title{
The Evantropian Project: Revitalising Critical Approaches to Young Adult Literature
}

\author{
Bugajska, A. (2019). Engineering youth: The evantropian project \\ in young adult dystopias. Ignatianum University Press.
}

\begin{abstract}
:
Anna Bugajska's recent book Engineering Youth: The Evantropian Project in Young Adult Dystopias (2019) is an important and thought-provoking inquiry into the field of young adult literary criticism. While for the average reader, young adult narratives may be associated with juvenile tales created with an intent to provide escapist entertainment, a true connoisseur of youth literature is well aware of an immense didactic potential of this genre. Bugajska certainly belongs to the latter category as she diligently engages with young adult dystopias to highlight the immense critical power of these texts. In the following review article, the author of the paper is going to offer a brief commentary on the critical perspective that $\mathrm{Bu}$ gajska employs to explore the notion of evantropia. The first section of this review discusses Bugajska's volume as a part of utopian intellectual tradition, the second section postulates that ideas presented in Engineering Youth enrich literary criticism in the field of speculative fiction and children's and young adult literature, the third section briefly discusses the layout of the volume and the content of each chapter, the fourth section presents an overview of selected core ideas that Bugajska presents in her work and in the last section the author of the paper offers his final thoughts on Engineering Youth.
\end{abstract}

Key words:

Anna Bugajska, young adult literature, dystopia, evantropia, science fiction, transhumanism

* Robert Gadowski - MA, prepares his doctoral dissertation at the Faculty of Letters at the University of Wrocław (Poland). In his doctoral thesis, he explores the notion of liberal democratic freedom in contemporary young adult dystopian literature. Currently Robert Gadowski works at the WSB University in Wrocław. Contact: robert.gadowski@gmail.com. 


\section{Projekt evantropijny. Rewitalizacja krytycznego podejścia do literatury młodych dorosłych}

\section{Bugajska, A. (2019). Engineering youth: The evantropian project in young adult dystopias. Ignatianum University Press.}

\section{Abstrakt:}

Najnowsza książka Anny Bugajskiej Engineering Youth: The Evantropian Project in Young Adult Dystopias (2019) jest pozycją, która wzbogaca badania z zakresu teorii literatury szczególnie w odniesieniu do literatury młodzieżowej. Dla przeciętnego czytelnika ten gatunek literacki może się wydawać jedynie rozrywką dającą ujście młodzieńczemu eskapizmowi, jednakże prawdziwy koneser tego typu literatury zauważy również jej niezmiernie wysoki potencjał dydaktyczny. Bugajska z całą pewnością należy do kategorii tych badaczy, którzy nie patrzą pobieżnie na literaturę młodzieżową. W książce $\mathrm{z}$ dużą dozą uwagi bada krytyczny charakter tekstów dystopijnych dla młodego czytelnika. W niniejszym artykule recenzyjnym autor zamierza przedstawić krótki komentarz na temat perspektywy badawczej przyjętej przez Bugajską, a opierającej się na koncepcji evantropi. Pierwsza część recenzji przedstawia książkę Bugajskiej w świetle bogatej tradycji myśli utopijnej, druga część zawiera tezę, iż teorie zaprezentowane w Engineering Youth znacząco wzbogacają badania nad literaturą spekulatywną, ze szczególnym uwzględnieniem literatury dziecięcej i młodzieżowej. W trzeciej części artykułu autor omawia plan książki oraz zawartość każdego z rozdziałów. Ostatnia, czwarta część została poświęcona kluczowym zagadnieniom zaprezentowanym w książce oraz podsumowaniu przemyśleń autora na temat dzieła Bugajskiej.

\section{Słowa kluczowe:}

Anna Bugajska, literatura młodzieżowa, dystopia, evantropia, science fiction, transhumanizm

\section{Introduction}

I $\mathrm{n}$ her thought-provoking book Engineering Youth: The Evantropian Project in Young Adult Dystopias, Anna Bugajska (2019) seems to indicate that current young adult dystopian fiction is often written with an intent to persuade young readers into appreciating, and perhaps even accepting a world radically transformed by biotechnology ${ }^{1}$ and biopolitics. ${ }^{2}$ In such a world humanity

1 Biotechnology is understood here as referring to technologies that promise to enhance human bodily and/or cognitive capabilities. An example of biotechnology in use would be genetic manipulation or implementation of technological devices into the human body.

2 Biopolitics is understood here in a broad sense, that is as political administration of human bodies. French philosopher Michael Foucault was among the pioneers of this field of study. 
stands at the crossroads, with one road leading to a utopian dreamland of endless possibilities, while the other taking a drastic dystopian turn. It appears that for Bugajska, the dystopian route is much more feasible as she moves to explore the nature of the literary project of evantropia.

The author's efforts to establish features of evantropian literary representations are the main focus of the volume. Bugajska (2019) explains that the evantropian project is aimed "to build a utopia in the human body with a range of available biotechnologies, and encompassing the holistically perceived human i.e., the physical, cognitive, emotional, and moral spheres" (p. 91). With this definition in mind, Bugajska manages to present powerful insights into the nature of social and technological changes that are looming over the horizon and may one day establish evantropian scenarios as a tangible, everyday reality for us all. ${ }^{3}$

\section{A Few Comments on the Structure and Coherence of the Book}

It must be said that Bugajska meets the demands of an interdisciplinary approach that an investigation of modern dystopian fiction requires. She is able to skillfully navigate through the conundrum of literary theories, political ideas, social ideologies, and techno-scientific novelties that all converge on the pages of contemporary young adult dystopian literature. Given the complexity of such an undertaking, it is no wonder that Engineering Youth is definitely impressive in its scope.

The clarity of the arguments and the effortless way Bugajska delivers them throughout the book need to be highly praised as well. The structure is clear and intuitive, a feature that promotes a worthwhile read. Importantly, all chapters work in unison to paint a distinct picture of what the evantropian project is, but a reader that is going to dedicate his or her time to concentrate only on one of the chapters will find that they can function well as a standalone piece.

Engineering Youth is divided into three lucidly delineated chapters. The first chapter is devoted to the exploration of the idea of evantropia. Bugajska indicates that the evantropian project is far from being a new phenomenon. In fact, evantropia has its roots in age-old intellectual strivings to achieve

For a compelling academic investigation of the ways the use of biotechnology will influence humanity, please see Visions: How Science Will Revolutionize the $21^{\text {st }}$ Century by Michio Kaku (1997). 
bodily perfection, reaching as far back as the Renaissance and the Age of Reason. Bugajska's take on evantropia was discussed with Lucas Misseri whose research predates Bugajska's own explorations. This collaboration was extremely fruitful when it comes to refining the definition of evantropia used in Engineering Youth. Bugajska (2019) notes that her extensive correspondence with Misseri:

[...] led us to the realization that the spheres of physical enhancement, medical humanities, and social policies are intertwined in this new vision of utopia to the extent that they are inseparable. Therefore, instead of splitting the idea and creating new terms for the separate facets of what appears to be the same problem, for the purposes of the present volume I adopted the term "evantropian project" (p. 36).

To stress the importance of evantropia, Bugajska juxtaposes it with the philosophy of transhumanism that also cherishes the exaltation of bodily transformations. The connections she makes are seamless and the line of argument is convincing enough to provoke a question why evantropia has been largely unexplored until recently. Another key element that Bugajska introduced in the first chapter is the notion of biovaluability which is meant to refer to use value of given biotechnologies. Biovaluability can be positive or negative depending on the specifics of evantropian literary representations of various biotechnologies.

The second chapter discusses evantropia's literary representations and aims to establish main features of the evantropian genre. This chapter provides a framework of reference for literary scholars who wish to consult their ideas with Bugajska's arguments on evantropia. Indeed, Bugajska demonstrates that evantropia must be treated seriously as a large literary project that emerges as a promising field of inquiry for scholars of dystopian fiction.

The third chapter is an analysis of major types of human enhancements as evidenced in the evantropian fiction today. Bugajska distinguishes physical, cognitive, emotional, and moral enhancements and provides insights into the way these are portrayed in youth fiction. According to Bugajska, some of them are very prospective when it comes to capturing the attention of potential consumers, while others have little appeal for the future biotechnological market. Bugajska's argument is that the value of various enhancements and body modifications will be ultimately determined by the attitudes and approaches that the evantropian fiction presents.

In the concluding chapter, Bugajska brings all the threads of the evantropian argument together and poignantly restates her vision. Notably, Bugajska 
does not shy away from complementing her conclusion with relatively strong claims concerning human enhancements and the role they perform in engineering the minds of young readers. Such a stance is deeply appreciated given the ongoing controversies surrounding the use of these technologies.

\section{Evantropia, Utopia, and Dystopia}

To fully appreciate the scope and depth of Bugajska's book, it is important to note that the notion of evantropia championed in Engineering Youth is a part of a long and rich history of utopian thought and its many renditions throughout the ages. However, utopia needs not to be relegated merely to the realm of literature. In fact, as history clearly shows, to deal with utopia is to step into a rich intellectual tradition that until this day has its numerous vestiges in politics, philosophy, and art. ${ }^{4}$ Indeed, utopian thinking is perhaps one of the most powerful and most pertinent features of human imagination. In particular, utopia envisioned as an ideal society has been an extremely potent concept in history, going as far back as the ancient Greece and the philosophy of Plato. The Greek philosopher was among the first to imagine a perfect society in his vision of an excellently organised city where human beings live peaceful, prosperous, and orderly lives. This Platonic ideal has been imprinted on political and philosophical discourse in the following ages, profoundly influencing such works as The City of God by St. Augustine (426 C.E./2009), Utopia by Thomas More (1516/1997), or The Social Contract by Jean-Jacques Rousseau (1762/1998). It can be argued that the two cornerstones of modern political ideologies of capitalism and communism came out of Adam Smith's and Karl Marx's utopian fascinations. ${ }^{5}$

With the advent of the $20^{\text {th }}$ century, utopian imagination was subject to a profound shift due to the traumas of failed utopian projects of the Bolshevik Revolution, Fascism and National Socialism, and later Soviet Communism. The accomplishments of these efforts were horror and misery. The dramatic fiasco of political attempts to establish utopian societies enacted through ubiquitous

4 For the sake of brevity, this review will not go into a detailed description of these.

5 A strong presence of utopian impulses in the works of Smith is addressed in The Adam Smith Problem: Reconciling Human Nature and Society in 'The Theory of Moral Sentiments' and 'Wealth of Nations' by Doğan Göçmen (2007), while the Marxist utopia has been a subject to numerous studies. One of the newest ones is The Perfect Society: Marx's Communist Revolution by A. V. Miles (2019). 
propaganda and state-sanctioned terror fully disclosed the horrifying possibility that technological means can be easily abused by the corrupt elites. The inconvenient truth that could be distilled from history is that to establish utopia in the real world one has to do it with complete disregard for moral and social repercussions. This dramatic realisation has found its expression in dystopian literature of the $20^{\text {th }}$ century with the seminal examples of Brave New World by Aldous Huxley (1932) and Nineteen Eighty-Four by George Orwell (1949). These classic dystopian novels display examples of future societies engineered through the abuse of innovative technologies that foster political coercion. Since the times of Huxley and Orwell, the influence of dystopian writings has been steadily growing, with its most popular renderings found today in the field of youth fiction.

Bugajska's main area of interest lies in the field of dystopia which she investigates with utmost vigor. She pays heed to the dire dystopian warnings, yet at the same time manages to imbue the discourse on dystopian writing with a fresh take on evantropia. Bugajska underscores the fact that evantropia has its distinct voice expressed through its unwavering focus on the significance of bodily transformation. It is important to note that while the questions of the manipulation of the body have always been a part of utopian and dystopian tradition, evantropian ideas discussed by Bugajska seem to correspond better to the contemporary outlook on the body as canvas, an idea that is often seen as the ultimate way to express one's freedom. In short, Engineering Youth manages to capture the zeitgeist of dystopian writing of the turn of the $21^{\text {st }}$ century.

In my view, Bugajska acknowledges the fact that the main focus of contemporary dystopias revolves around the question on the nature of freedom and how the usage of novel technologies can either make or break freedom of an individual. The idea of individual freedom, or rather morphological freedom $^{6}$ to manipulate one's own body, is contrasted with the collectivist impulse to treat the body of the citizens as a subject to the policies of the state. It seems that Engineering Youth posits an interesting inquiry into the viability of utopian collectivism in the times of a nascent of unabashed individualism that is facilitated by new technological inventions.

6 Morphological freedom refers an idea that it is a basic human right to modify one's own body according to one's wishes. A violation of this freedom would be a forceful manipulation of a person's body, for example a mutilation. 


\section{Evantropia and Science Fiction}

Bugajska's book is also a scholarly work that deals with the nature of speculative fiction as a literary platform that provides space for thought experiments on technologically mediated realities and the limits of scientific progress. In my view, Engineering Youth is, therefore, a valuable addition to the literary criticism in the area of speculative fiction, and in particular, to young adult science fiction scholarship. This should come as no surprise since dystopias typically nestle themselves in the convention of science fiction, an extremely popular genre on its own that has the literary means to extrapolate on the future use of techno-science and its social and cultural impact. Given this context, it seems that Isaac Asimov's (1975) astute remark that "[s]cience fiction writers foresee the inevitable, and although problems and catastrophes may be inevitable, solutions are not" can be applied to contemporary dystopian writers as well. Indeed, dystopian authors take special interest in gradual transformation of modern cultural fabric by technological and political means. It is apparent that Bugajska (2019) is well aware of this fact when she states: "The re-cognition of the symbiotic relationship between science and literature would be necessary to accept before delving into the evantropian dimension of the studied texts" (p. 94). This powerful coupling of literature and science proved to be extremely successful in recent times when the literary market has been overflown with dystopian writings that haunt the popular imagination with an alarmist tone about the grim future that awaits humanity.

In relation to Bugajska's research, it must be noted that speculative literature for young readers has been gaining much recognition in recent years as evidenced by a number of literary scholars that locate their interest in the careful investigation of young adult dystopian genre. Thus, Bugajska's Engineering Youth should be seen as a beneficiary of such influential examinations of the topic as Representations of Technology in Science Fiction for Young People by Noga Applebaum (2009), Technology and Identity in Young Adult Fiction: The Posthuman Subject by Victoria Flanagan (2014), and Children's Literature and the Posthuman: Animal, Environment, Cyborg by Zoe Jaques (2015), just to name a few. Nevertheless, despite their immense academic craftsmanship, the above-mentioned volumes (and similar installments in children's and young adult literary criticism) still have their limitations. For instance, a typical manner of investigating transhuman philosophy in literature for young readers relies on probing particular philosophical notions postulated by transhumanism, for example the question concerning human identity in relation 
to gradual cyborgisation ${ }^{7}$ of the human body. Yet such a perspective could be further enriched with an in-depth analysis of specific technologies that make this transhuman reality possible. ${ }^{8}$ It may be argued that Bugajska's Engineering Youth promises to deliver a new critical outlook that fills the niche in literary criticism. Bugajska does this by providing an overview of technologies that are presented in young adult dystopian fiction and highlighting the importance of a practical evaluation of the potential application and impact these technologies can have. In other words, Bugajska manages to show that evantropian literary visions can have a practical dimension, thereby eclipsing abstract academic debate and showing that evantropia is grounded in our immediate experience of technology.

\section{Commentary on Selected Key Ideas}

\section{Evantropian Project}

The evantropian project is the main focus of the book. I have already mentioned that evantropia is treated by Bugajska as a literary endeavor that focuses on the representation of bodily perfection. When it comes to the evidence $\mathrm{Bu}$ gajska submits, I believe that the way she connects theoretical framework with the analytical part of her work makes for a powerful cumulative argument that evantropia possesses an explanatory power and scope very useful for the analysis of dystopias writings. Still, in my opinion, the best thing about Bugajska's approach to evantropia is that she deliberately avoids the trappings of dogmatism regarding the issue of the definition of evantropia. To her credit, Bugajska never actually assumes the role of an authority whose position on evantropia should not be contested. To illustrate this attitude, Bugajska states in the conclusion that she declined to point to any text as exemplary of evantropian fiction. She explains this approach in the following manner:

7 Cyborgisation is taken to mean an enhancement of the body with technological devices. These devices need not to be inserted into the body, but can assume a role of an extension of the body functions. For example, it can be argued that contemporary overreliance on IT technologies is a sign of cyborgisation, since human beings cannot properly function in many areas of life without an immediate access to a computer or a cell phone.

8 Trans- and posthumanist fascination with the plasticity of identity sometimes tilts the balance between the exploration of the concept of identity and the analysis of the nature of biotechnologies in favor of the former, whereas the latter is consigned to the background of the research. 
It would not be easy to defend the stance that in the juvenile - or, for that matter - adult literary output we can arrive at a paradigmatic evantropia. Rather, the evantropian spirit will be more or less pronounced, sometimes present in an overwhelming, sometimes in a nuanced way (Bugajska, 2019, p. 235).

Thus, Bugajska's desire to escape the rigid definition for evantropia can be seen as a celebration of scholarly freedom. This is also evidenced when she discusses the connection of evantropia and $\mathrm{H}+$ dystopia. ${ }^{9}$ Bugajska states that "evantropia [is] a larger socio-ideological project whose outgrowths can be discerned in the H+ dystopia" (p. 26). It seems to me that Bugajska means here that her goal is to promote her arguments as a tentative template, rather than a strict rubric for the critical examination of literary presence of evantropia. This is a smart choice since solid definitions often prove to be a burden for scholars of literary fiction.

\section{Evantropia's Transformative Power}

In Engineering Youth, Bugajska (2019) underscores the power of fiction to shape the hearts and minds through "emotion-laden narration and the cultural perception of human enhancement" (p. 91). In the context of evantropia, such a power is applied to change the perception of biotechnology and transhuman values among the youth. It seems that Bugajska strongly upholds the notion that evantropia possesses a profoundly transformative power. This way of thinking discloses a connection of Bugajska's methodology to the idea of transformative utopianism put forth by Clare Bradford, Kerry Mallan, John Stephens, and Robyn McCallum (2008) in their New World Orders in Contemporary Children's Literature: Utopian Transformations. The authors believe that the utopian mantle has been taken up by young adult literature and has been reinvigorated by a new form of utopianism that takes into consideration the horrors of the past, but at the same time remains optimistic about the possibilities of tomorrow. This phenomenon is called "transformative utopianism", which is:

[...] based on the assumption that works of fiction employ utopian and dystopian themes and motifs in a way that has a transformative purpose: that is, they propose or imply new social and political arrangements by imaging transformed world orders (p. 6).

$9 \mathrm{H}+$ dystopia is a term Bugajska uses to denote dystopian writing with a profound influence of transhumanist ideology. 
Bugajska's vision of evantropia certainly can be read as an attempt to highlight the transformative power of dystopian fiction. For Bugajska, even in dystopian nightmares, evantropian literature still manages to salvage the emancipatory power of utopian thinking. Furthermore, evantropian transformative power rests on its ability to incorporate the discussion on newest technologies, particularly the ones that focus on the betterment of human condition and enhancement of body and mind. In short, Bugajska is successful in presenting evantropia as an incubator for literary experiments aimed to dissect the intriguing questions about the impact of biotechnology on human nature and human society.

\section{Evantropia and Transhumanism}

Another choice made by Bugajska that needs to be highly praised is her approach towards transhumanism. Bugajska addresses transhumanism as a social movement that has a considerable impact on the way that people approach technological change. This view is very pragmatic since transhumanism is sometimes underestimated when it comes to its culture-shaping influences. Bugajska seems to indicate that Western culture is de facto a culture heavily mediated by transhumanist agenda, even if the main tenants of transhumanism are often only covertly present in popular culture. What is more, Bugajska manages to excavate deeper layers of meaning in transhumanist thought that at the first glance may remain hidden. In particular, Bugajska's take on mythological and even quasi-religious imagery used by transhumanists is praiseworthy. In relation to evantropia, it could be argued that the conquest of the limitations of the human body is framed as a sacred war against imperfection, much like in mythological tales, human condition is framed as feeble and undesirable when compared to the abilities of the gods. Fixation with godlike status may be something that transhumanists do not consciously ascribe to, nonetheless, as Bugajska observes, "the figure of the fire-bearing Prometheus as the patron saint of the movement, lending his name to prometheism - a transhumanist cult preaching salvation through technology" (Bugajska, 2019, p. 53) discloses the fact that this tendency is strongly present in transhumanism.

\section{Final Remarks}

In The Dystopian Impulse in Modern Literature, M. Keith Booker (1994) claims that dystopian fiction has a unique capacity to present "fresh perspectives on 
problematic social and political practices that might otherwise be taken for granted or considered natural and inevitable" (p. 19). It is my deep conviction that Engineering Youth is one of the best modern scholarly examinations of this phenomenon. Bugajska's volume proves that dystopian writing for young readers cannot be dismissed as a simple negation of the utopian impulse, nor as a genre that is used only to display negative examples of social and political corruption. In her exploration of the idea of evantropia, Bugajska manages to capture the transformative impulse embedded in modern dystopian narratives for the young audience. Her focus on the evantropian project and the transformations of the body is a brilliant choice given the socio-cultural milieu that idealises bodily perfection but often forsakes a closer examination of the costs of achieving body enhancements.

In my view, Bugajska's efforts must be highly commended because, if successful, her methodology could not only be a significant addition to the critical voices that engage with young adult literature, but may also become an important perspective for the new way of approaching dystopian fiction. Furthermore, even though Engineering Youth is an expert study, it is my conviction that it can also be very informative for the average reader who enjoys young adult dystopian speculative fiction and wants to supplement his or her knowledge of the genre. To sum up, Engineering Youth is a book highly recommended for academics and casual readers.

\section{References}

Applebaum, N. (2009). Representations of technology in science fiction for young people. Routledge.

Asimov, I. (1975). How easy to see the future! Natural History, 84(4), 92.

Booker, M. K. (1994). The dystopian impulse in modern literature. Praeger.

Bradfrod, C., Mallan, K., Stephens, J., \& McCallum, R. (2008). New world orders in contemporary children's literature: Utopian transformations. Palgrave Macmillan.

Bugajska, A. (2019). Engineering youth: The evantropian project in young adult dystopias. Ignatianum University Press.

Flanagan, V. (2014). Technology and identity in young adult fiction: The posthuman subject. Palgrave Macmillan.

Göçmen, D. (2007). The Adam Smith problem: Reconciling human nature and society in 'The Theory of Moral Sentiments' and 'Wealth of Nations.' I. B. Tauris.

Huxley, A. (1932). Brave new world. Chatto \& Windus. 
Jaques, Z. (2015). Children's literature and the posthuman: Animal, environment, cyborg. Routledge.

Kaku, M. (1997). Visions: How science will revolutionize the $21^{\text {st }}$ century. Anchor Books. Miles, A. V. (2019). The perfect society: Marx's communist revolution. Nuova Publishing. More, T. (1997). Utopia. Dover Publications. (Original work published 1516).

Orwell, G. (1949). Nineteen eighty-four: A novel. Sacker \& Warburg.

Rousseau, J.-J. (1998). The social contract. Wordsworth Editions Limited. (Original work published 1762).

St. Augustine. (2009). The city of God. Hendrickson. (426 C.E.). 